\title{
BEING AN INTERNATIONAL LAW LECTURER IN THE 21ST CENTURY: WHERE TRADITION MEETS INNOVATION
}

\author{
Freya Baetens ${ }^{*}$ \\ Cheah Wui Ling ${ }^{\dagger}$
}

\begin{abstract}
This paper examines the legal tradition of teaching and researching international law at universities all over the world, in order to achieve two main goals. First, this paper maps diverse national and regional legal traditions in teaching and researching international law. For example, what topics are addressed for which target audience? Who teaches international law in preparation for which professions? Can one speak of an Asian, as opposed to an African, European, Latin American or North American way of teaching and researching international law? Secondly, this paper calls for a codification of 'good practices' in teaching and researching international law so as to take its global aspirations seriously.
\end{abstract}

\section{Keywords}

International law, legal education, legal profession, legal research, open access

\section{Introduction}

One means to bring about this desirable condition [settling international controversies without war] is to increase the general public knowledge of international rights and duties and to promote a popular habit of reading and thinking about international affairs. ${ }^{1}$

\footnotetext{
* Freya Baetens (Cand./Lic.Jur. (Ghent); LL.M. (Columbia); Ph.D. (Cambridge)) is Associate Professor of Law, Director of Studies and Head of the LUC Research Centre at Leiden University and Visiting Professor at the World Trade Institute (WTI) in Berne. As associate lawyer with VVGB (Brussels Bar), she regularly acts as counsel or expert in international disputes.

${ }^{\dagger}$ CHEAH Wui Ling (LL.B./LL.M. (NUS); LLM (Harvard)) is Assistant Professor at the Faculty of Law of the National University of Singapore (NUS). She is a qualified lawyer, called to the New York Bar. She also serves as a Senior Adviser for the Forum for International Criminal and Humanitarian Law and an Editor for the Torkel Opsahl Academic EPublisher. She would like to acknowledge the helpful research assistance provided by MAK Shinyi, Jason LEE, and Dione WONG in collecting empirical data on international law research for this article. The authors are grateful for the feedback received from the organisers and participants of Cambridge Journal of International and Comparative Law (CJICL) Conference Legal Tradition in a Diverse World (18 and 19 May 2013, University of Cambridge).

1 E Root, 'The need of popular understanding of international law' (1907) 1 AJIL 1, 2.
}

Copyright $\odot$ the Author(s).

This work is licensed under a Creative Commons Attribution-NonCommercial-NoDerivs 3.0 License. 
US Secretary of State Elihu Root published this call for education of the public in matters of international law on the first page of the first issue of the American Journal of International Law-and it remains as important today as it was in 1907. This paper examines the legal tradition of teaching and researching international law at universities all over the world, in order to achieve two main goals. First, this paper maps diverse national and regional legal traditions in teaching and researching international law. For example, what topics are addressed for which target audience? Who teaches international law in preparation for which professions? Can one speak of an Asian, as opposed to an African, European, Latin-American or North-American way of teaching and researching international law? Second, this paper calls for a codification of 'good practices' in teaching and researching international law so as to take its global aspirations seriously. Only then can research-led teaching introduce students to different histories and conceptions of international law, in a manner that encourages sensitivity and respect. This is crucial to maintaining the legitimacy and relevance of international law, as it seeks to constructively engage a global audience that is ever more astute and critical.

This commitment impacts what is being taught and researched, as well as how this is done. International law lecturers need to facilitate student engagement with potentially unfamiliar ideas in a meaningful way, which in turn influences scholarship as a whole. To ensure a high-quality diversity of voices in international law, our research and publication processes need to be structured to overcome barriers of resources and access. Educators and researchers have begun to develop and implement a variety of innovative strategies and tools in the teaching and research of international law, such as open access policies, accessible internet platforms, joint anthologies and teaching collaborations. By highlighting positive examples, this paper suggests ways to build upon tradition and use innovation so as to move forward as teachers and scholars of international law. It should also be noted at this point that this is an ongoing research project. The findings and analysis presented in this paper are therefore preliminary in nature, with the aim of encouraging exchange and debate. 


\section{Mapping national and regional traditions in teaching international law}

\subsection{Research methodology: quantitative and qualitative data}

The methodology which underlies this part of the paper on teaching international law is two-pronged: the authors have conducted an extensive quantitative study of international law courses taught at universities worldwide, which has been complemented by a qualitative analysis based on the discussions and writings of international law lecturers in academic literature as well as within the framework of the International Law Association (ILA).

With regard to the quantitative research part of the project, the authors have collected their empirical data on international law courses based on the information provided by law schools on their official websites. ${ }^{2}$ This unfortunately entails the risk that such information is incomplete or not up-to-date. Furthermore, due to the sheer number of law schools, a selection had to be made. For this purpose, the authors have opted to examine international law courses offered at 150 law schools worldwide, based on the rankings of the 'most popular' law schools according to the LLM GUIDE:

LLM GUIDE aims to provide the most comprehensive and up-todate guide of Master of Laws (LLM) programs available on the internet. LLM GUIDE also publishes original content that we think will be of interest to prospective LLM students. Finally, our website provides a forum where people can ask questions, discuss, and exchange information about topics related to LLM programs in a positive environment.

The monthly rankings in the Most Popular LLM Programs section are determined by the number of user page views per LLM program listing. Therefore, the popular LLM programs are simply the programs that LLM GUIDE users have viewed most frequently. The number of user page views also determines the of LLM programs in the geographic-based program searches. ${ }^{3}$

\footnotetext{
${ }^{2}$ International law courses taught at international relations or political science schools have not been included in the survey.

$3<$ http://www.llm-guide.com/llm-faq $>$ [accessed 14 September 2013].
} 
The authors realise that this 'popularity' selection criterion is open to criticism but nevertheless opted to use this online database as a starting point of the present study for the following reasons. First, it is a widely used source of information which allows prospective students to compare LLM programmes. Reportedly, many students' application choices are (at least partially) based on information obtained from the LLM GUIDE. Second, it is a database which compiles input from visitors from all over the world-leading to a more neutral or balanced list for our purposes, compared to country-based lists such as the Times Higher Education ranking or the Shanghai list. ${ }^{4}$ Third, contrary to lists which rank universities as a whole, LLM GUIDE rankings are focused on law schools, so the data are not influenced by, for example, very well-performing medical schools. Fourth, LLM GUIDE rankings are based on student input, so teaching experiences have a much larger impact on a school's ranking than the number of Nobel Prizes or A-list publications of its staff members (although the latter may also be taken into account by students who wish to find out more about a certain school). The relatively modest influence of teaching practices (as opposed to, for example, citations of faculty members' papers $)^{5}$ on the place of a university in global rankings is an oft-lamented issue ${ }^{6}$ which, particularly for this paper, needs to be re-assessed. Fifth and finally, 'most popular' does not necessarily mean 'qualitatively best'; however, 'most popular' does imply that these schools in many ways set the standards for other schools, so their international law practices, both at LLM and LLB level, deserve most scrutiny.

More specifically, the authors have analysed data of 25 law schools in the USA;

4 <http://www.timeshighereducation.co.uk/world-university-rankings/>; <http://www.shangha iranking.com/ARWU2012.html> [accessed 14 September 2013].

5 See e.g. T Eisenberg \& M T Wells, 'Ranking and explaining the scholarly impact of law schools' (1998) 27 The Journal of Legal Studies 373; A L Brophy, 'The relationship between law review citations and law school rankings' (2006) 39 Conn L Rev 43; R Perry, 'Correlation versus causality: further thoughts on the law review/law school liaison' (2006) 39 Conn L Rev 77.

6 This concern does not only affect law school rankings for the purpose of international law teaching, but for university-level legal education in general. See e.g. Symposium Issue, Indiana Law Journal, 'The next generation of law school rankings', in particular: R A Posner, 'Framing the rankings debate' (2006) 81 Indiana LJ 13; B Leiter, 'How to rank law schools', (2006) 81 Indiana LJ 47; J E Stake, 'The interplay between law school rankings, reputations and resource allocation: ways rankings mislead', (2006) 81 Indiana LJ 229. For an alternative model of ranking law schools, see e.g. B Leiter, 'A ranking of U.S. law schools by educational quality', <http://www.leiterrankings.com> [accessed 14 September 2013], as discussed in G C Sisk, D Hackerson, M Wells \& V Aggerbeck, 'Scholarly impact of law school faculties: extending the Leiter rankings to the top 70 (2010)' University of St. Thomas Legal Studies Research Paper No 10-24, <http://dx.doi.org/10.2139/ssrn.1674764> [accessed 15 October 2013]. 
25 in the Americas (outside of the USA); 25 in the UK and Ireland; 25 in Europe (outside of the UK and Ireland); 15 in Africa; 25 in Asia and 10 in Australia and New Zealand. For each of these, the following issues were examined:

- Which topics are addressed in international law courses (e.g. use of force, treaty law)?

- Who is the target audience and is this a mandatory or a voluntary course for these students (e.g. first year undergraduate, final year undergraduate, master's student)?

- Which sources are relied upon (e.g. which reading and other materials are used)?

- Who teaches international law (e.g. profile of professors: practitioners and/or academics)?

- Is a link made between international law and legal practice (e.g. through clinics, moot courts, internships, law clerkships, etc)?

The authors chose to focus on these issues because they give a good insight into the extent to which international law engages today's law students in an inclusive and relevant manner.

With regard to the qualitative research part of the project: the authors have relied on discussions among and interviews with international law lecturers, for example within the ILA Committee on the Teaching of International Law, ${ }^{7}$ as well as several previous studies. ${ }^{8}$ These have been referred to in the footnotes where appropriate, but two papers deserving particular mentioning: John Gamble's 'International law teaching: glass(es) half full? Rose colored? Red/white and blue?' and Charlotte Ku's 'International law: what to teach and why?'-both of

7 J Gamble \& N Botha, 'International Law Association Committee on the teaching of international law, final report' in Report of the Seventy Fourth Conference, The Hague (2010) ILA Publications; 'Meeting report of International Law Association Committee on the teaching of international law' in Report of the Seventy Fifth Conference, Sofia (2012) ILA Publications, forthcoming.

${ }^{8}$ One of the first large-scale academic studies of international law teaching in schools of law and of political science was conducted in 1912 in the framework of the American Society of International Law (ASIL): Carnegie Endowment for International Peace Report on the Teaching of International Law in the Educational Institutions of the United States (1913). A follow-up study was conducted in 1963: R W Edwards, International Legal Studies: A Survey of Teaching in America Law Schools (1963-1964). The next update was J Gamble, Teaching International Law in the 1990s (1992). 
which provide interesting insights into the US teaching practice. ${ }^{9}$ Throughout the paper reference is made to data obtained from interviews, particularly when a large majority of interviewees, independently from one another, shared a similar approach or opinion. ${ }^{10}$

Based on the data thus retrieved, the authors have answered the following questions: what are common or region-specific obstacles to the communication of international legal knowledge to students in an applicable and globally sensitive manner? Can one speak of an Asian, as opposed to an African, European, Latin-American or North-American way of teaching international law? The answers to these questions in turn serve as a basis for the subsequent section in this paper, in which the authors set out a number of best practices in relation to the research of international law-as the foundation upon which university-level teaching is based.

\subsection{Commonalities and diversities in international law courses}

\subsubsection{Topics taught}

There are some clear commonalities in the lecture topics of international law which were found in virtually every course curriculum examined. These are: sources of law; legal subjects; use of force; human rights; and international dispute settlement. There are also notable differences; for example, at many law schools, there is strong emphasis on treaty law in all its aspects, relegating customary law and general principles to a 'second-rank' place (which does not entirely square with their-at least officially-equal importance within the hierarchy of sources of international law). Other law schools, not surprisingly in common law countries, seem to elevate case law to the top of the sources hierarchy, almost treating it as a primary rather than subsidiary source. Within the topic of legal subjects, some schools (for example those in Eastern Europe and Asia) discuss sovereign states to the exclusion of nigh all other possible

9 Both papers are on file with the authors and an abbreviated version will be published in the 'Meeting report of the International Law Association Committee on the teaching of international law', in Report of the Seventy Fifth Conference, Sofia (2012) ILA Publications, forthcoming.

${ }^{10}$ Many lecturers expressed significant concerns about the confidentiality of their answers, so all interview data have been anonymised. Should readers be interested in examining more specific raw data, the authors are willing to share these, along with relevant details such as geographical location and the interviewee's level of seniority, keeping in mind the need to limit information to prevent identification and maintain confidentiality. 
subjects. Yet other schools extensively discuss the role of regional organisations, individuals and even mankind as a whole (Europe and Africa).

With regard to the use of force, the findings are unsurprising: in the US and a number of like-minded states, the government's official policy has clearly permeated academic teaching. Humanitarian intervention and pre-emptive strike are included as largely, if not entirely, accepted justifications for the use of force, in addition to collective security and self-defence. The large majority of courses address human rights but, understandably, focus mainly on the international covenants, except in countries where a regional human rights convention is in force (Latin-America, Africa and Europe). Regarding international dispute settlement, most courses focus only or mainly on the International Court of Justice, but others also mention international arbitration and (rarely) forms of alternative dispute resolution.

Some sub-fields of international law, such as international environmental law, international economic law and international criminal law, are taught mainly at western universities, although international economic law in its various aspects (trade, investment and finance) is gaining ground at African universities. There are also significant differences between countries regarding the attention paid to the implementation of international law in the domestic system, which is most often elaborated upon in-depth at common law universities.

\subsubsection{Audience and mandatory/voluntary status of the course}

International law is offered as a subject at all examined universities and in many (but not all) law schools, and it is a mandatory course in the LLB programme (with the exception of the US where law as such can only be studied at graduate level). Even at universities where the study of international law is not mandatory, such as the Law Tripos at Cambridge, most students choose to take it in practice. Several universities, such as NYU and Leiden, offer a specialised LLM programme that solely focuses on international law topics, but even at universities which do not have specialised tracks, it is often possible to pursue an LLM degree by taking solely or mostly international law courses.

\subsubsection{Teaching and reading materials}

Broadly speaking, two trends can be discerned in the use of teaching and reading materials which roughly seem to be based on the common law versus civil law divide. At universities in the UK, Ireland, New Zealand and Australia, interna- 
tional law is taught with a heavy focus on its development through case law, including the decisions of national courts implementing international rules (or the national laws incorporating them). In continental Europe and Latin-America, international law is taught by emphasising the theoretical structure of the system, relying on analysis in scholarly writings.

The US is somewhat of an in-between case as so-called Restatements are used, which are a set of treatises that seek to inform judges and lawyers. ${ }^{11}$ They are essentially codifications of case law, based on judge-made doctrines that have developed gradually because of the principle of stare decisis, or binding precedent. Although Restatements do not form binding authority in and of themselves, they are considered highly persuasive because they have been formulated over several years with extensive input from law professors, practising attorneys and judges. They are meant to reflect the consensus of the American legal community as to what the law is (and in some cases, what it should become).

Evidently, every set of materials has its advantages and disadvantages: common law students might lose sight of the larger international law forest due to their focus on individual case law trees, while civil law students are heavily influenced by the particular approach of whoever happens to be the author of their textbook. An additional problem for the latter is that English is often not their mother tongue and if their textbook is not written in English either, it becomes difficult for them ever to grasp the full meaning of the rules as expressed in the original materials (treaties, case law) which are most often written in English.

\subsection{Profiling the international law teacher}

One does not necessarily need to have taken an international law course as a student in order to be subsequently successful as a teacher of international law. Gamble recalls, for example, that he once asked an assembly of members of the American Society of International Law (ASIL) in the 1990s how many in the group had not taken an international law course while pursuing their first degree in law and to his surprise, among others, Abram Chayes and Louis Henkin 'somewhat sheepishly' raised their hands. ${ }^{12}$ Interestingly, none of the Europeans present at the meeting did so, which could indicate that the entry of international law as a mandatory course within law school curricula occurred

${ }_{11}$ American Law Institute, Restatement of the Law (Third): Foreign Relations Law of the United States.

12 J Gamble, 'International law teaching: glass(es) half full? Rose colored? Red/white and blue?' in Report of the Seventy Fifth Conference, Sofia (2012) ILA Publications, forthcoming. 
earlier in Europe. Admittedly, some more candid readers could equally suggest that European international law teachers are less eager to make such a confession than their US counterparts.

What is sorely needed for all lecturers, not merely those lecturing international law, is the re-valuing of the teaching aspect of the job. To put it in a caricatural manner, teaching sometimes seems to have become something every selfrespecting, ambitious academic ought to run away from as soon as possible. ${ }^{13}$ If after some years in academia, one still has a heavy teaching load, it is almost viewed as a sign that one has not been successful in the more prestigious aspects of the academic job, such as research or management. Generally speaking, looking at faculty profiles world-wide, junior academics (assistant and associate professor level) are involved in three or four courses on average, with not-to-be-envied exceptions who have to perform in seven or eight courses. For senior academics (full professors), this number drops to one or two courses on average, with exceptions teaching four or five. ${ }^{14}$ If one is to calculate the actual amount of teaching hours, ${ }^{15}$ taking into account lecture time (but not lecture preparation as well as setting and correcting exams) and time spent practising with students in seminar groups, clinics and moot courts (but not research supervision time), the disparity between junior and senior lecturers is even greater. This is not to say that senior faculty work less hours-but they spend (significantly) less hours teaching.

It is impossible to compute the precise average teaching time put in by individual faculty members, as their web profiles often do not mention the specific allocation of each lecturer within a course. For example, an international law course in an LLB programme consists in many countries of plenary lectures of two hours per week taught by a senior lecturer, as well as seminar sessions in smaller groups, taught by junior lecturers. If such a course lasts five weeks, the senior lecturer will have taught 10 hours, while a junior lecturer covering five smaller groups will have been required to teach 50 hours. In the light of the fact that junior lecturers are on average involved in more courses and typically take on more groups within these courses, it can be concluded that world-wide, the least experienced seem to be carrying the heaviest teaching load. However, it needs to

\footnotetext{
${ }^{13}$ This could be caused by the fact that teaching evaluations play a very small role in the ranking of law schools, as examined in the literature referred to in above $\mathrm{n} 5$ and 6 .

${ }^{14}$ For both groups, only the official courses in the curriculum were counted, although many academics teach extra hours as guest lecturers.

${ }^{15}$ Here the local system was adopted to calculate hours, so an hour was counted as an hour if the law school calls it so, bearing in mind that some universities apply a 'one hour equals 45 minutes of teaching' system.
} 
be emphasised that this is a generalised finding, bearing in mind that there are differences between universities and even within universities, between different departments. Some law schools have a stricter policy whereby all staff members are allocated an equal load of teaching hours. One way to promote the research and development of early career academics is to allocate them lighter instead of heavier teaching loads. ${ }^{16}$

Moreover, in some countries (e.g. Germany or the UK), law schools do not have a separate 'international law department', so international law lecturers are linked to the public law department as such. Thus they are required to teach not only international law, but also EU law, national public law, constitutional law, administrative law, land law or tax law. All interviewees who participated in this study and who are working in such a system were asked whether, based on their own perception, they are up-to-date with developments in each of the fields they teach. Not a single interviewee responded that (s)he was. Apart from the personal anguish of having to teach a subject which one barely knows better than the students whom one is teaching, this is also detrimental to the students themselves as it deprives them from gaining insights a true specialist in the matter could have offered them-which is exactly the advantage of university-level teaching.

Additionally, at many universities in continental Europe (unlike the UK and the US), if a course is taught by several lecturers, the course convener tends to be the most junior person on the list. On the one hand, this is understandable, as convening a course entails significantly more (mainly administrative and logistical) work than lecturing in it. On the other hand and weighing in much more heavily, junior lecturers do not yet have the experience senior lecturers have-so it is rather counterintuitive to give them the bulk of additional work, bearing in mind that preparing their lectures properly already takes them more time than it would for a senior member of staff. Several interviewees noted that after taking care of all organisational elements relating to the course, they were too exhausted to prepare the lectures themselves in the manner and at the depth which they would have preferred and would have felt comfortable with. In the words of one interviewee, the most he could do, was 'to stay one week ahead of the students'.

Many universities today offer their staff members some form of teaching skills courses, including how to approach diversity in the classroom and how

${ }^{16}$ For example, the National University of Singapore, the home institution of one of the co-authors, allows new faculty to claim a certain amount of teaching relief upon completing mid-term reviews. 
to objectively evaluate students and how to give constructive feedback. In most universities, participation in such courses seems, however, to be mostly obligatory for junior staff members, while senior members are simply assumed to be natural-born teachers, researchers, supervisors, fundraisers, managers, etc. Aside from the perceived unfairness on the part of the junior lecturers who have to invest substantial time in such skills courses, a number of senior interviewees expressed interest in participating but also hesitance at 'being seen attending', as if this would equal admitting that they 'had been doing it wrong for years'. The fairest solution would seem to be that, similar to what is the case in many countries for practising members of the Bar, a system be put in place whereby all members of staff annually have to earn a number of 'skills credits'. Where a more junior member might for example opt for a course on setting exams, a more senior member might benefit from a seminar on using e-learning environments.

\subsection{Linking international law and legal practice}

Louis Henkin noted in 1979 that:

[t]oday, international law is taught in the universities, practiced by lawyers, weighed by foreign offices, invoked by governments in relations with other governments. About the scope of international law, however, about its role in international relations, about its influence in foreign policies of nations, there is little agreement and, I dare say, little learning and much misunderstanding. ${ }^{17}$

\subsubsection{The lecturer as living link between theory and practice}

Unfortunately, such misunderstandings continue to exist to this day, largely due to the increasing 'academisation' of the teaching profession. Fifty years ago, rather few (international) law professors were solely academics, regardless of the university they were teaching at. ${ }^{18}$ Their practice enriched their teaching and vice versa-while simultaneously, students obtained a realistic picture of the job possibilities offered by the study of (international) law. Today, lawyers are forced to choose: either practice or academia-possibly one followed by the other and some people seem to be yo-yoing back and forth in their careers, but the simultaneous pursuit of both is increasingly being rooted out.

\footnotetext{
${ }^{17}$ L Henkin, How Nations Behave $\left(2^{\text {nd }}\right.$ edn, 1979) 2.

${ }^{18}$ RJ Wilson, 'The role of practice in legal education' in K B Brown \& D V Snyder, General Reports of the 17th Congress of the International Academy of Comparative Law (2012) 57.
} 
Admittedly, some abuses had to be remedied, as teaching often landed rather low on the priority list, but the cure seems to be worse than the disease and has seriously impoverished the capabilities of lecturers to link international law and practice in a meaningful manner. There are a number of exceptions to this rule, such as James Crawford at Cambridge, Alain Pellet at Paris X or Philippe Sands at University College London. Readers should hereby bear in mind that 'international legal practice' is far from limited to its (perhaps most spectacular) form of arguing cases before the International Court of Justice (ICJ) or the International Criminal Court (ICC). Most international law is debated before national courts; as became visible in the Pinochet case before the English House of Lords, the Somali piracy cases before the Dutch Courts and the countless international trade rules which, after being incorporated in domestic law, form the legal basis of many national disputes. ${ }^{19}$ And even if academics do not follow a litigation vocation, obtaining practical experience is not limited to court work: it also includes working for NGOs, being part of expert committees drafting national statutes to implement international law, being an in-house counsel for a multinational, etc.

However, it is an outstanding matter whether junior lecturers will be able to follow in the footsteps of these examples as the data show many of them report to be so pressed with teaching, publication and fundraising requirements that they lack the energy to build up their practice in addition-provided that their departments would even allow them to. This is a highly negative development, not only for the teaching of international law, as lecturers cannot teach about practice they do not know, but also for their individual development. It makes lecturers unsuitable for any other job and thereby removes their option of choosing a different career path later in life-which several interviewees directly blamed for the burn-out, or at least 'severely diminished enthusiasm', of many colleagues.

To make matters worse, even were this deterioration in the well-versedness of lecturers to be recognised, it would be difficult to turn the tide, as by then, law schools might be governed by people who never obtained any practical experience-and what one has never experienced, one often does not miss. One solution would be to establish more part-time lectureship positions with the possibility of obtaining tenure (unlike the current US practice). This is practically already possible at many universities, albeit for other reasons such as parenthood,

${ }^{19}$ In Re Pinochet [1999] UKHL 1; LJN BY6943, Gerechtshof's-Gravenhage, 22-004047-11 (20 December 2012); LJN BR4930, Rechtbank Rotterdam, 10/960248-10 (12 August 2011). 
but it would be hard to defend that the care for a child is an acceptable reason for part-time work, while one's personal development is not-particularly as the latter also directly benefits the students. Courses can easily be (and often are already) taught by more than one person, this would even enhance the student experience as part of university level education is to be exposed to different styles and approaches.

\subsubsection{Mimicking practice: moot courts}

In actual practice, it is very unlikely one will ever be asked to sum-up the Montevideo criteria for statehood or to define most-favoured-nation treatment, but lawyers working for a government might well receive a request for advice on the recognition of Kosovo as a state and those associated with a law firm might have to examine whether non-discrimination rules have been violated by the adoption of a particular trade measure. In this light, another useful way of linking theory to practice is for students to 'pretend' they are practising lawyers, by means of a fictitious case. The authors have not been able to find even one lecturer who had participated in a moot court and afterwards considered it a waste of time. A small but not negligible number of interviewees did express doubts as to the usefulness of moot courts (particularly the intensive practice sessions which precede the actual moot) - none of whom, again without exception, had participated in a moot court as a student themselves. Unlike the concerns put forward in the previous section on the increasing academisation of the international legal teaching profession, there is a more positive trend emerging regarding the perception of moot courts.

Without making any claim to exhaustiveness and in addition to the many internal moot courts set up within universities, students can participate in a wide variety of international law moot courts organised at the global level, focusing on public international law in general (Philip C Jessup; Telders), ${ }^{20}$ human rights (René Cassin; Inter-American Human Rights Moot Court), ${ }^{21}$ criminal law (ICC Trial Moot Court), ${ }^{22}$ trade law (WTO Elsa), ${ }^{23}$ investment law (Frankfurt Investment Arbitration Moot Court; Foreign Direct Investment International

\footnotetext{
${ }^{20}<$ http://www.ilsa.org/jessup/>; <http://www.grotiuscentre.org/TeldersMootCourt.aspx> [accessed 14 September 2013].

${ }^{21}<$ http://www.concourscassin.eu/>; <http://www.wcl.american.edu/hracademy/mcourt/index _en.cfm $>$ [accessed 14 September 2013].

$22<$ http://www.icc-trialcompetition.org/> [accessed 14 September 2013].

${ }^{23}<\mathrm{http}$ ://www.elsamootcourt.org/> [accessed 14 September 2013].
} 
Arbitration Moot), ${ }^{24}$ humanitarian law (Frits Kalshoven; Jean-Pictet) ${ }^{25}$ and space law (Manfred Lachs). ${ }^{26}$ If there is one comment common to all students who have participated in such moot courts, it is that they have learned much more from them than from most taught courses-which also puts in perspective the effectiveness of the traditional ex cathedra style of lecturing.

Luckily, law schools worldwide are starting to understand this, leading to over 550 schools participating in the Jessup competition for example. Also, funding agencies and academic and professional societies are increasingly seeing the relevance of moot courts as an indispensable part of students' legal training and are supporting the travel and accommodation costs of teams. More can be done, however, to support teams in terms of rewarding the time invested, as many law schools still regard mooting as a useful extra-curricular activity but are not willing to actually include it into the curriculum and offer course credit for participation in a moot court. Also, if mooting is to be generally recognised as a desirable fixed element in every law programme, it ought to be made mandatory for all students. Not all will be able to participate in an international moot court so alternatives ought to be devised within the law school itself-a practice which has already been adopted by a great number of continental European, UK and US universities.

\subsubsection{Tasting practice: internships and clerkships}

A final way in which students can be shown how the theoretical study of international law is linked to its legal practice is through internships and clerkships. Unfortunately, this still seems to be the privilege of students at universities in Western Europe, the UK and (to a lesser extent) the US. In particular, universities that are conveniently located near one of the centres of international law (New York, Geneva and The Hague) manage to gain a significant advantage over other universities when it comes to attracting students from all over the world. Some of the wealthier institutions have secured internships for some of their students with, for example, the UN Headquarters, the ICJ and the Permanent Court of Arbitration by concluding specific agreements.

\footnotetext{
${ }^{24}<\mathrm{http}: / /$ www.merton-zentrum.uni-frankfurt.de/Start/FIAC_International_Student_Moot_Co urt/ $>$; <http://www.fdimoot.org/> [accessed14 September 2013].

${ }^{25}<$ http://www.rodekruis.nl/dit-zijn-we/humanitair-oorlogsrecht/ihlcompetition/about/pagina s/default.aspx >; <http://www.concourspictet.org/index_en.htm> [accessed 14 September 2013].

${ }^{26}<$ http://www.iislweb.org/lachsmoot/> [accessed 14 September 2013].
} 
A ready solution does not lie at hand, as living in these cities for three to six months is extremely expensive by all students' standards and places are limited. Nevertheless, also in this area, additional efforts could be made in terms of offering places more widely (for example, at domestic courts and tribunals which deal with international law, such as the International Crimes Division of the High Court of Uganda) as well as procuring funding for students to take up such positions. In addition, many developing country missions to the UN or the WTO, for example, welcome interested students (regardless of nationality) as they do not have the funds to employ sufficient full-time delegates themselves to follow all relevant meetings. Providing students with access as widely as possible to participate in such internship programmes is particularly important because many positions at international organisations, for example at the ICC, are often offered to people who have previously interned there.

\subsection{Preliminary conclusions on the teaching of international law}

Clear commonalities exist in the choice of international law topics in the examined course curricula, such as sources of law, legal subjects and use of force-although the precise content and approach may differ. Some sub-fields of international law, such as international environmental law, international economic law and international criminal law, are commonly included in western law schools, but not beyond. International law is offered as a subject at all examined universities and in many law schools, it is a mandatory course. Broadly speaking, two trends can be discerned in the use of teaching and reading materials which roughly seem to be based on the common versus civil law divide: a heavy focus on the development of international rules through case law versus an emphasis on the theoretical structure of the system, as analysed in scholarly writings.

The present paper urgently calls for a re-evaluation of the teaching part of international law lectureships. Junior lecturers are, on average, involved in more courses and typically take on more groups within these courses, so worldwide, the least experienced often seem to be carrying the heaviest teaching load. However, this is a generalised finding, bearing in mind that there are differences between and within universities. In law schools which do not have a separate 'international law department', international law lecturers are linked to the public law department and have to teach a wide variety of courses. This makes it impossible for them to remain up-to-date with developments in each 
of these fields - to the detriment of the academic quality of their lectures and, ultimately, the education of their students.

Additionally, if a course is taught by several lecturers, the course convener tends to be the most junior person on the list, although they do not yet have the experience senior lecturers have. It is rather counterintuitive to give them the bulk of additional work, bearing in mind that preparing their lectures properly already takes them more time than it would for a senior member of staff. In most universities, participation in skills courses is obligatory for junior staff members, while merely optional for senior members. This paper advocates the adoption of a system whereby all members of staff annually have to earn a number of 'skills credits'.

The 'academisation' of the international law lectureship has seriously impoverished the capabilities of lecturers to link international law and practice in a meaningful manner. 'International legal practice' is far from limited to arguing cases before the ICJ or the ICC as most international law is debated before national courts. Obtaining practical experience is moreover, not limited to court work: it also includes working for NGOs, being part of expert committees drafting national statutes to implement international law, being an in-house counsel for a multinational, etc.

Students who have participated in international moot courts commonly remark that they have learned much more from them than from most taught courses-which also puts in perspective the effectiveness of the traditional ex cathedra style of lecturing. Luckily, law schools worldwide are starting to understand this, while funding agencies and academic and professional societies are increasingly seeing the relevance of moot courts as an indispensable part of students' legal training and are supporting the travel and accommodation costs of teams. More can be done to support teams in terms of rewarding the time invested, by incorporating moot courts in the curriculum and offering course credit for participation. Internships and clerkships unfortunately still seem to be the privilege of students at universities in Western Europe, the UK and (to a lesser extent) the US. Efforts should be made in terms of offering places more widely as well as procuring funding for students to take up such positions.

In sum, there are some common obstacles to the communication of international legal knowledge to students in an applicable and globally sensitive manner. These are usually not region-specific but rather correspond to the common law or civil legal tradition: there is no Asian, as opposed to an African, European, Latin-American or North-American way of teaching international law-with the exception, perhaps of the reliance on the US Restatements at US law schools. This 
analysis of teaching practices serves as a basis for the subsequent section, in which a number of best practices in relation to the research of international law are set out-as the essential foundation upon which university-level teaching is based.

\section{Ensuring inclusion and diversity in international law research}

\subsection{Research questions and methodology}

In this part of the paper, the authors focus on research trends and practices in international law. It proceeds based on the belief that for international law to be truly legitimate at a global level, it must generate knowledge that is truly representative and inclusive in nature. It must aim to transcend the boundaries set by geography, economics, culture or demography. We examine the state of international law research from three perspectives: access, capacity and collaboration. Specifically, we discuss the need to ensure accessibility of knowledge and research on international law, the need to address non-scientific research barriers and the need to facilitate the equal exchange of ideas between researchers.

This section adopts the following approach and methodology in addressing its questions of access, capacity and collaboration. To provide us with a snapshot of the type of international law research being conducted and where such research is being published, we examined lists of journal rankings compiled by a number of research organisations. ${ }^{27}$ As it is common practice among academics to consider a journal's ranking when deciding which journal to submit their article for publication and as highly ranked journals thus have a larger pool of articles to choose from when deciding which articles to publish, it is reasonable to

\footnotetext{
${ }^{27}$ Lists of ten journals each were constructed based on an across the board analysis of rankings by Washington \& Lee, Google, Stirling and Siemslegal (a blog which made use of 2008 RAE data), bearing in mind the strong US focus of the list by Washington \& Lee and the strong UK/Europe focus of RAE data. They were classified based on their editorial background and purported focus: general global journals, American journals, European journals, Asian journals, African journals and Latin American journals. We ruled out journals that were very new or did not focus much on international law. For the Asian and African list, we primarily relied on Washington \& Lee's listing of 'Asian law' and 'African law', identifying the journals dealing with international law. Many of these journals were assigned a low or no impact factor. The Latin American list was constructed based on the LATINEX database, which is a collaboration between various research institutions across Latin America, but also including Spain and Portugal. The Latin American list was compiled in no particular order.
} 
conclude that the articles published in these journals will be of a higher quality and relevance. These highly ranked journals may be seen as a source of high quality international law knowledge.

Based on these global lists and additional research, we then compiled lists of regional journals based on the journal's editorial composition and its stated regional emphasis. This enabled us to construct lists of well-reputed journals by region. We presumed that with their purported regional emphasis, these journals give special attention to region-specific topics and perspectives. They therefore serve as a high quality source of region-specific legal knowledge. In putting together these global and regional lists based on journal rankings as an indicator of research quality, we recognise that we are relying on the quality controls established by these journals' peer-review system and reputation. We acknowledge, however, that these rankings can serve only as general benchmarks and that the quality of research should be judged by its content rather than the ranking of the journal in which it was published.

This section's analysis of research trends in international law proceeds as follows: first, based on an analysis of our empirical data, we provide an overview of research practices in a particular area. Second, we evaluate the inclusivity and representativeness of these practices, highlighting some progressive developments. Last, we put forward suggestions to improve research access, capacity and collaboration. It making our proposals, we draw on some practices first developed within non-law disciplines, such as natural sciences and medicine. We do try, as much as possible, to refer to examples from the discipline of international law. Given the preliminary and ongoing nature of our research, the examples put forward in this paper are largely from the authors' areas of expertise and are not intended as a complete survey of innovative exercises in the field of international law. As we hope for our paper to serve as a point of reference for those interested in such best practices, we would be happy to include other international law examples brought to our attention in future studies.

\subsection{Equal access to resources and the open access movement}

Access to existing research is necessary for the creation of new research findings and theories. Indeed, as observed by many scholars, research is never completely 'new' in nature. Rather, all research builds on and benefits from previous research done by others. Access to existing research is thus a precondition for further research. This research process has generally become a much more convenient affair today. By accessing online journal subscriptions, e-books and research 
databases, many academics from developed countries are able to get all the information they need for their research without leaving their desks or offices. Rather than searching for information, they are inundated instead with too much information. Various software has been developed to assist researchers in the managing and organising of their research material and many universities in developed countries now run courses on the use of such software. ${ }^{28}$ Not all academics are in this fortunate position. These include those from institutions or societies that do not have the financial resources to pay the subscription fees charged by commercial publishers or database companies for access to such research. Most academic institutions in developing countries are unable to afford these subscription fees. ${ }^{29}$

Private publishers and database providers offer valuable services which have greatly contributed to improving research quality and speed. However, this does not justify the oftentimes excessive fees charged. Current practices are arguably too profit-oriented and not justified by the cost of the research and publishing process. ${ }^{30}$ Take journal publishing practices as an example. The researcher does not require any fee for turning over his or her research findings and article to the publisher. He or she considers him- or herself remunerated for the research through his or her salary from his or her academic institution. Research costs are usually covered by the researcher's academic institution or external funding sources. Upon being submitted to the journal concerned, the research article is assessed and refined by peer-reviewers and editors who are academics and provide these services without charge. Upon the article's acceptance and though the researcher does not receive any financial remuneration for the published article, he or she is required to sign over all copyright to the publisher concerned. By insisting on exclusive copyright and charging high subscription fees, the publisher limits access of the research article to those who can afford it.

Currently, this continues to be the publishing model subscribed to by most international law journals. Though there are an increasing number of journals, the CJICL included, that provide complete access to their articles at no cost on

\footnotetext{
${ }^{28}$ Examples of such software include EndNote, Mendeley and Zotero. The latter two are free software.

${ }^{29}$ See, for example, OUP's policy on offering access at free or reduced prices for some articles and journals to developing countries: <http://www.oxfordjournals.org/access_purchase/develo ping_countries.html $>$ [accessed 8 May 2013].

${ }^{30}$ G Monbiot, 'Academic publishers make Murdoch look like a socialist', The Guardian, $29 \mathrm{Au}-$ gust 2011, <http://www.theguardian.com/commentisfree/2011/aug/29/academic-publishersmurdoch-socialist> [accessed 22 September 2013].
} 
their websites, these continue to be exceptions to the rule. A number of journals on our global and regional lists provide complete or significant levels of open access to their articles. ${ }^{31}$ Others require authors to pay a certain fee for their articles to be published on an open access basis. ${ }^{32}$ But a substantial number continue to provide access only to fee-paying subscribers. As further explained below, there have been an increasing number of open access developments that, if properly implemented, can further facilitate access to international law research.

\subsubsection{The development and dissemination of open access tools}

The past decade has seen the rise and spread of the open access movement within academia. ${ }^{33}$ A decade ago, researchers and institutions set up the Budapest Open Access Initiative to encourage open access efforts. It published a set of guidelines to which hundreds of institutions and universities have pledged their support. ${ }^{34}$ Universities that have signed on to these guidelines include the European University Institute, Harvard University and Oxford University Libraries. Open access advocates argue that academic research should be made available to the general public on an unrestricted and free-of-charge basis. From a human rights perspective, open access plays an important role in fulfilling the human right 'to enjoy the benefits of scientific progress and its applications', which is recognised by Article 15(1)(b) of the International Covenant of Economic, Social and Cultural Rights (ICESCR). ${ }^{35}$

Researchers have long been able to self-archive their works-in-progress via various internet platforms, such as SSRN. ${ }^{36}$ However, researchers are often

${ }^{31}$ Journals providing complete open access include the Harvard International Law Journal, the Michigan Journal of International Law and the German Law Journal. Some provide extensive though not complete open access. For example, the European Journal of International Law's archive includes all published articles 'until one year prior to the present', see $<$ http://www.ejil.org/archives.php > [accessed 15 October 2013].

${ }^{32}$ Examples are journals published by Oxford University Press that permit authors to sign on to the Oxford Open Policy.

${ }^{33}$ M Laakso, P Welling, H Bukvova, L Nyman, B Björk \& T Hedlund, 'The development of open access journal publishing from 1993 to 2009' (2011) PLoS ONE e20961; A Swan, 'Policy guidelines for the development and promotion of open access' (2012) UNESCO (hereinafter '2012 UNESCO Guidelines').

${ }^{34}<\mathrm{http}$ ://www.opensocietyfoundations.org/openaccess/read> [accessed 8 May 2013].

${ }^{35}$ For a comprehensive discussion of open access from a human rights perspective, see A B Skre \& A Eide, "The human right to benefit from advances in science and promotion of openly accessible publications' (2013) 31 NJHR 427.

${ }^{36}<$ http://www.ssrn.com/> [accessed 8 May 2013]. 
prevented from disseminating their research in its final published form because of the publisher's requirement that authors sign over all author rights to a piece of work. ${ }^{37}$ Many researchers are not aware that this is not reasonable in light of the actual cost and nature of the publishing process and need to be educated about alternatives that will ensure that they are given due credit and recognition, while allowing them to widely disseminate their work. In reality, most researchers do not have the know-how or time to design licensing alternatives with which they can enter into negotiations with publishers. Recognising this, a non-profit company has developed a range of Creative Commons Licenses with which researchers can secure different levels of public access to their work. ${ }^{38}$ This still requires the researcher to be willing to take the time to negotiate with the publisher concerned and the publisher to be willing to make exceptions to the journal's publishing practices.

A number of academic journals have adjusted their publishing practices to allow authors to choose different publishing routes. Some journals have moved to publishing on a complete open access basis or provide their authors with the option to do so. This, among open access advocates, is known as publishing via the 'gold' route. ${ }^{39}$ Some journals permit researchers to self-archive their articles. This is known as the 'green' route. ${ }^{40}$ Others allow authors to make a single article of theirs available on an open access basis by paying a particular fee. This is known in the open access world as the 'hybrid' route. ${ }^{41}$ The natural sciences lead in this open access development, while the humanities lag significantly behind. ${ }^{42}$ An example of an open access publisher in international law would be the Torkel Opsahl Academic EPublisher that provides full access to international law publications through its website. ${ }^{43}$ Another important development is the design

${ }^{37} 2012$ UNESCO Guidelines.

${ }^{38}<$ http://creativecommons.org/licenses/> [accessed 8 May 2013].

${ }^{39} 2012$ UNESCO Guidelines, 22.

${ }^{40}$ Ibid, 20.

${ }^{41}$ Ibid, 22-23.

${ }^{42} \mathrm{Ibid}, 20,26$. Percentage of articles in open access journals/self-archived: Earth sciences (7/25.9); Mathematics (8.1/17.5); Social sciences (5.6/17.9); Physics (3/20.5). Distribution of open access repositories by region: Europe (47 per cent); North America (20 per cent); Asia (19 per cent); Africa (3 per cent).

${ }^{43}$ The Torkel Opsahl Academic EPublisher (TOAEP) is the publishing arm of the Centre for International Law and Research and Policy (CILRAP), whose webpages are translated into different languages: English, Spanish, French, Japanese, Mandarin, Arabic, Portuguese, Bahasa Indonesia and Dutch. Its commitment to language diversity may explain the wide reach of the centre's website. In April 2013, there were more than 25,000 hits to CILRAP webpages, with 17,947 to the FICHL/TOAEP site (by 2,290 unique visitors). One of this paper's authors (Cheah 
of online databases that house research publications on an open access basis. These databases come equipped with search engines that enable researchers to locate publications based on key words. For example, the International Criminal Court's Legal Tools Database (LTD) contains a repository of academic articles deposited by authors on an open access basis. ${ }^{44}$ Such databases, when equipped with a search engine, allow researchers to locate research materials quickly.

\subsubsection{Embedding open access into institutions}

In 2012, UNESCO published a report in support of open access, based on its constitutional function to 'maintain, increase and diffuse knowledge. ${ }^{45}$ The development and widespread dissemination of open access tools, such as open access repositories where authors can deposit their work, has been crucial to the spread of the open access movement. For example, the Directory of Open Access Journals serves as a gateway to 9,035 open access journals from 120 countries and comes with a convenient search engine. ${ }^{46}$ Advocates of open access are tracking and promoting open access developments with the aim of educating researchers, institutions and funders. The innovative Open Access Map records and follows open access initiatives all over the world, demonstrating the open access movement's global spread. ${ }^{47}$ Despite the development and spread of such open access tools, how realistic is it to expect academics, particularly early-career researchers, to voluntarily submit their research to open access journals or publishers? Lists of international journal rankings are widely used, formally or informally, by academic institutions and academics to assess the quality of publications. ${ }^{48}$ Most highly ranked academic journals or publishers still do not practice open access. Researchers are faced with the choice of publishing in an open access journal that is viewed as less prestigious or publishing in a highly

\footnotetext{
Wui Ling) is on the editorial board.

44 <http://www.legal-tools.org/en/what-are-the-icc-legal-tools/> [accessed 8 May 2013]. The LTD also provides online access to over 61,000 documents, including national legislation, national cases of core international crimes, international cases and legislation, all preparatory works of the ICC, its Statute, rules, regulations, judgments, decisions and orders and relevant international and regional human rights decisions.

${ }^{45}$ Article 1, UNESCO Constitution.

${ }^{46}<$ http://www.doaj.org/> [accessed 8 May 2013].

$47<$ http://www.openaccessmap.org/> [accessed 8 May 2013].

${ }^{48}$ See, for example, the list released by the Australian Research Council: <http://www.arc.gov. au/era/era_2012/era_journal_list.htm> [accessed 8 May 2013].
} 
ranking journal that does not practise open access. For early-career researchers, this choice will often affect their chances at tenure or promotion.

Institutional open access policies are therefore required to avoid disadvantaging those who choose to publish in open access journals. Institutions are gradually but slowly putting in place open access policies. A number of prestigious universities have lent their name to the open access movement by publicly adopting open access policies. ${ }^{49}$ Harvard has adopted an open access policy that requires academics of faculties that have signed on to this policy to provide the university with their scholarly articles that are then made publicly available via an online repository, called DASH. ${ }^{50}$ To facilitate such open access publication, Harvard University provides its academics with a convenient addendum generator that will enable them to propose publication agreement amendments to potential publishers. ${ }^{51}$ Other universities, such as Oxford University, have adopted more flexible policies that support but do not mandate open access. Researchers who wish to publish open access are provided with the guidance and tools enabling them to do so, such as online institutional depositories. ${ }^{52}$

More importantly, public and private funders of research have started to require fund recipients to make their published research findings available on an open access basis. For example, in 2012, the UK Research Councils announced their new open access policy which makes it mandatory for peer reviewed papers resulting from research wholly or partially funded by such councils to be published in journals that at least offer a 'pay to publish' option or allow deposition in an open access repository after a maximum embargo period of one to two years, with the exact embargo period depending on the discipline. ${ }^{53}$ Since early 2013, the US Congress has been considering the Fair Access to Science and Technology Research Act (FASTR) which will require open access to publications that report on federally-funded research. ${ }^{54}$ At the EU level, open access is required of all scientific publications funded by Horizon 2020, an EU funding programme for research and innovation. ${ }^{55}$ Encouragingly, a 2013 study commissioned by the European Commission has announced that over 50 per cent

\footnotetext{
${ }^{49}<$ http://osc.hul.harvard.edu/policies $>$ [accessed 8 May 2013].

${ }^{50}<\mathrm{http}: / /$ dash.harvard.edu/> [accessed 8 May 2013].

${ }^{51}<\mathrm{http}$ ///osc.hul.harvard.edu/authors/policy_guide> [accessed 8 May 2013].

${ }^{52}<$ http://www.bodleian.ox.ac.uk/science/resources/open-access> [accessed 8 May 2013].

$53<$ http://www.rcuk.ac.uk/research/Pages/outputs.aspx> [accessed 8 May 2013].

${ }^{54}<$ http://cyber.law.harvard.edu/hoap/Notes_on_the_Fair_Access_to_Science_and_Technology _Research_Act> [accessed 8 Mary 2013].

${ }^{55}<$ http://ec.europa.eu/research/horizon2020/index_en.cfm?pg=h2020> [accessed 22 September 2013].
} 
of research published in 2011 is currently available on an open access basis, though the same study also noted that the humanities and social sciences are among disciplines lagging behind in their open access practices. ${ }^{56}$

\subsection{Capacity-building through mentorship and editorship}

Apart from access to existing research, academics need to master a mix of 'scientific' and 'non-scientific' skills to excel in their research fields. 'Scientific' skills refer to substantive knowledge about one's research topic or area. As an example, for a scholar of international law, this may include knowledge about the sources of international law, treatises and relevant case law. 'Non-scientific' skills are often seen as incidental to academia, but these are in reality essential for a researcher to excel in the academic world. Examples of such skills include knowing how to draft grant proposals, how to network with other colleagues in one's area and how to locate various funding opportunities. Having such skills is often as important as having substantive knowledge about the research topic when trying to get a research project off the ground. This similarly applies to the teaching of international law, where knowing how to design course syllabi, how to effectively engage students and how to utilise teaching technology, is often as important as knowing the substance of one's course.

Some researchers, such as those in the early part of their research careers or those from developing countries, may not have had the opportunity to learn these skills, particularly those that are 'non-scientific' in nature. This may be due to factors unrelated to research ability, such as a lack of exposure to academic culture or a lack of specific linguistic ability. The latter is especially important. With one or two exceptions, the journals in our compiled European, African and Asian lists publish solely in the English language. ${ }^{57}$ Interestingly, on its website, the Asian Journal of International Law clarifies that its decision

${ }^{56}<\mathrm{http}$ ///europa.eu/rapid/press-release_IP-13-786_en.htm> [accessed 22 September 2013].

${ }^{57}$ The fact that we compiled our lists based on global rankings published by Anglophone research organisations, such as the Washington \& Lee list, may affect our lists. An exception to this is our list of Latin American journals, three of which are Spanish. The European Journal of International Law used to be bilingual, but now publishes in English. On its website, the journal explains that it adheres to 'a strong belief in the central importance of linguistic diversity to the continued flourishing of international law' and that 'the decision to publish exclusively in English is based on the fact that it enables us to reach the widest possible readership, in view of the ever-growing number of Europeans and others for whom English is the principal second language.' The journal however states that it 'warmly welcome[s] submissions in French, Spanish, Italian and German' and when 'resources permit' will endeavour to translate those accepted for publication into English: <http://www.ejil.org/about/index.php> [accessed 22 September 
to publish in English is due to 'practical convenience' rather than 'political endorsement. ${ }^{58}$ This disadvantages researchers who do not have English as their mother tongue. Such barriers of academic culture and language can be overcome through capacity-building. As used in this paper, capacity-building aims to empower their subjects with the knowledge and tools that will enable them to design and execute their own solutions to any identified problems. It recognises that we live in a world where resources are unequally distributed, that such resource inequalities need to be addressed and that having a certain level of resources is necessary for one to act effectively in any area.

\subsubsection{Academic mentorship}

Having the guidance and advice of a more experienced academic greatly facilitates the growth and development of a junior academic. Research demonstrates that junior academics who were given guidance by senior academics achieved more than those who did not have access to such guidance. ${ }^{59}$ Mentored junior academics out-performed their peers in terms of publications produced, publications accepted by highly ranked journals and successful funding applications. As most universities evaluate their academic staff based on such criteria, mentored academics would be in a stronger institutional position compared with their non-mentored peers. Research also shows that postgraduate researchers whose supervisors actively mentored them not only produced more publications, but also viewed their research experience in a more positive light. ${ }^{60}$

Recognising this, many universities have put in place formal or informal mentorship programmes that enable early career academics or aspiring researchers to work with a more senior colleague. ${ }^{61}$ Existing research notes that such mentorship practices are less developed in the faculties of social science and law where

2013]. The African Journal of International and Comparative Law accepts submissions in English and French: <http://www.euppublishing.com/page/ajicl/submissions > [accessed 22 September 2013].

${ }^{58}<$ http://journals.cambridge.org/action/displayMoreInfo?jid=AJL\&type=ifc> $\quad$ [accessed 22 September 2013].

${ }^{59}$ F D Blau, J M Currie, R T A Croson \& D K Ginther, 'Can mentoring help female assistant professors? Interim results from a randomized trial' (2010) 100 American Economic Review 348.

${ }^{60} \mathrm{~A}$ K Scaffidi \& J E Berman, 'A positive postdoctoral experience is related to quality supervision and career mentoring, collaborations, networking and a nurturing research environment' (2011) 62 Higher Education 685, 686-687.

${ }^{61}$ See, for example, Teaching Support Centre, University of Western Ontario, 'Western guide to mentorship in academia' (2008), <https://www.uwo.ca/tsc/resources/pdf/PG_2_mentor ing.pdf $>$ [accessed 10 December 2013]. 
research is often conducted independently. ${ }^{62}$ Establishing such mentorship programmes requires careful planning. While too much rigidity or formality may be undesirable, mentorship programmes should clearly set out the scope and objectives of such mentorship, so mentors and mentees are aware of what is expected of them. Mentors should also be given due recognition for their participation in the programme. Some guidance on mentor-mentee interaction would also be useful. Given existing, if unspoken of, hierarchies in academia, the expectations and experiences of a senior academic may be very different from that of a junior academic. Mentors and mentees need to be educated about the perceptions, needs and expectations of the other party. For example, mentors should be encouraged to first approach their mentees as the latter may feel unwilling to 'bother' their mentors. ${ }^{63}$ Mentees, on the other hand, should be respectful of their mentors' personal space and time.

Mentorship has been shown to benefits member of groups that are inadequately represented within academia, such as women and racial minorities. ${ }^{64} \mathrm{Just}$ as in any workplace, minorities may find it more difficult to understand and navigate the practices and expectations established by the majority. This may be especially problematic in academia, where work processes are less formal and where much academic networking takes place on an unofficial basis. While mentors do not necessarily have to be from the same minority group, they need to be sensitive to the challenges faced by academics from such minority groups. One such mentorship programme targets all female scientists and was founded for the benefit of women (formerly) linked to Max Planck Institutes: Minerva FemmeNet. ${ }^{65}$ In the area of international law, the ASIL's women interest group has most recently implemented a women's mentorship programme. ${ }^{66}$

Some mentorship programmes bring together researchers and educators from developed and developing countries. If designed properly, these programmes can facilitate skills transfer and build long term capacity. For example, from 2008-2012, the National University of Singapore (NUS), the University of Malaya, the Australian National University and Universitas Indonesia took part

\footnotetext{
${ }^{62}$ Scaffidi \& Berman, above n 60, 688 .

${ }^{63}$ Teaching Support Centre, above n 61, 9.

${ }^{64}$ Blau \& others, above n 59; M N Davidson \& L Foster-Johnson, 'Mentoring in the preparation of graduate researchers of colour' (2001) 71 Review of Educational Research 549.

65 <http://www.gendera.eu/index.php5?file=12\&dq_id=65> [accessed 8 May 2013].

${ }^{66}$ This programme has just been initiated and has issued a widespread call for mentors and mentees. For example, see call issued at <http://ilg2.org/2013/04/03/please-attend-asilmentoring-event-this-thursday/> [accessed 8 May 2013].
} 
in an international law capacity building programme aimed at meeting the needs of the Faculty of Law of Syiah Kuala University in Indonesia. ${ }^{67}$ As part of this programme, lecturers from Syiah Kuala University were posted to NUS where they attended lectures and seminars in their areas of focus. They also had the opportunity to consult with NUS lecturers and work with them to develop their course syllabi. Most of the participants from Syiah Kuala University spoke very enthusiastically of their experience. ${ }^{68}$ While the mentee is undoubtedly the primary beneficiary of mentorship programmes, with proper planning and training, mentors can also benefit much from such programmes.

\subsubsection{Overcoming language barriers}

Language is an obvious, but seldom discussed, roadblock to participation in academic research at the international level. For various reasons, English has become the de facto lingua franca of the academic world, including that of international law. ${ }^{69}$ Anglophone writers usually have an advantage over non-Anglophone authors when articulating and arguing complex ideas in English. The widespread use of English at the international level is closely linked to Anglo-American dominance and results in discursive biases. Just as how the stylistic features of judicial decisions are influenced by the particular legal tradition from which they emanate, so too are the stylistic features of academic writing influenced by the cultural background of their authors. ${ }^{70}$ A 2011 qualitative social science research project, focusing on the experience of Spanish researchers, highlights the difficulties experienced by non-Anglophone researchers when expressing their ideas in English. ${ }^{71}$ Among other things, these researchers report having particular difficulties in drafting the rhetorical or persuasive portions of academic articles, such as the article's introduction. ${ }^{72}$ Interestingly, the majority of academics interviewed in this research project did not think that their linguistic disadvantage

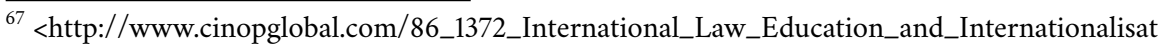
ion.aspx>; <http://www.cinopglobal.com/1_1324_About_CINOP.aspx > [accessed 8 May 2013].

${ }^{68}$ Information on file with authors.

${ }^{69}$ For a critical overview, see F Salager-Meyer, 'Scientific publishing in developing countries: challenges for the future' (2008) 7 Journal of English for Academic Purposes 121.

${ }^{70}$ A Watson, 'Legal change: sources of law and legal culture' (1983) 131 University of Pennsylvania Law Review 1121.

${ }^{71}$ C Pérez-Llantada, R Plo \& G R Ferguson, “You don't say what you know, only what you can”: The perceptions and practices of senior Spanish academics regarding research dissemination in English' (2011) 30 English for Specific Purposes 18.

${ }^{72}$ Ibid, 24.
} 
resulted in the rejection of their work for publication. ${ }^{73}$ While research is inconclusive, some commentators argue that having the ability to present one's arguments in a way that is familiar to one's peer-reviewers and editors, many of whom will be native English speakers, does increase one's chances of publication. ${ }^{74}$

This language barrier can be overcome by employing highly skilled translation services, but such services are expensive and out of the reach of researchers from less developed countries. Another possibility is for journals and publishers to allow articles to be submitted and peer-reviewed in languages other than English. An example would be the German online journal, Zeitschrift für Internationale Strafrechtdogmatik (Review of International Criminal Law Doctrine) ${ }^{75}$ However, there are undeniable benefits to having one's work published and disseminated in a globally understood language, such as English. Journals and publishers could offer English translation or editing services and this would require them to employ staff with the necessary linguistic skills. Such translation work brings with it dangers of its own. The translator will need to be generally familiar with the legal topic at hand. For such translation to be done well, there needs to be close cooperation between the author, translator and editor. The original non-English article could also be published alongside the translated end product to give readers access to the former as well. Though laborious, it is not impossible. The Torkel Opsahl Academic EPublisher has published a number of international law works in English as well as in the native language of the author or target society. ${ }^{76}$ In the long term, adopting such publishing practices may encourage more international law students, particularly those in Anglo-American institutions, to learn and master languages apart from English.

Such time and labour intensive processes do not fit well with the workload and schedules of today's journal editors, peer-reviewers and publishers who are continuously harangued by submission backlogs. Advances in technology and communications have made the preparation and submission of articles much easier, at least, for those who have the means to do. Simultaneously, a tendency has developed on the part of journal editors and publishers to be more exacting in standards, including language standards. This may adversely impact assessments of work by non-Anglophone authors. Scholars from developing countries, although perhaps fluent in English, may not express themselves in

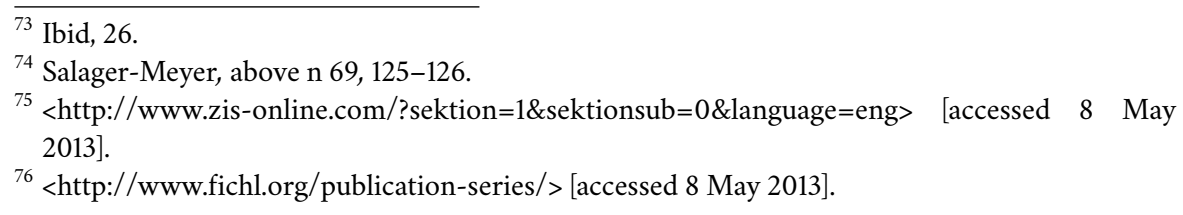


a manner comparable to native English speakers from developed countries. Some journals expressly request authors to consider sending their work to professional proof-readers before submitting it to the journal. For example, both the websites of Oxford and Cambridge University Press Journals advise authors who are non-native English speakers to consider having their articles 'professionally edited. ${ }^{77}$ This, it is explained, serves to ensure that the article's content is fully understood by journal editors and reviewers. ${ }^{78}$ Just as the cost of professional translation services prevent many from using them, so too do the costs of professional editing services put them beyond the financial reach of most researchers from developing countries.

Researchers have highlighted how an author's access to 'language brokers' enhances publication prospects, particularly in international English journals. This research also identified power imbalances between 'language brokers' and non-Anglophone authors, which may result in the unconscious if well-meaning distortion of the latter's research by the former. The ability to access 'language brokers' who are academics and who provide substantive advice beyond the phrasing of ideas in technical English gives some non-Anglophone authors an advantage over others, particularly at the submission for publication stage. ${ }^{79}$ If we aim to publish the research of non-Anglophone authors that are worthy of dissemination, even if these are expressed in a manner that appears somewhat awkward to native English writers, we need to reconceptualise the role of editors. $^{80}$

When assessing submissions, editors could view themselves as 'language brokers' committed to cooperating with the author in preparing his or her work for publication. ${ }^{81}$ Such editors would need to be familiar with the subject matter on the submitted paper and be prepared to work closely with the author to improve the manner in which ideas are expressed. Editors should be aware of the

\footnotetext{
$\overline{77}<$ http://www.oxfordjournals.org/for_authors/language_services.html $>$; $<$ http://journals.camb ridge. org $/$ action $/$ stream?pageId $=8728 \&$ level $=2 \&$ menu $=$ Authors\&pageId $=3608>$ [accessed 8 May 2013].

${ }^{78}$ These websites provide a list of third-party commercial entities providing editing services, with a disclaimer that the publisher does not endorse or take responsibility for the work of these entities: <http://www.oxfordjournals.org/for_authors/language_services.html > [accessed 23 September 2013]; $<$ http://journals.cambridge.org/action/stream?pageId=8728\&level=2> [accessed 23 September 2013].

${ }^{79}$ T Lillis \& M J Curry, 'Professional academic writing by multilingual scholars: interactions with literacy brokers in the production of English-medium texts' (2006) 23 Written Communication 3.

${ }^{80}$ Salager-Meyer, above $\mathrm{n} 69$.

${ }^{81}$ Lillis \& Curry, above $\mathrm{n} 79$.
} 
dangers highlighted by research on 'language brokering' and endeavour to respect the content and nuance of arguments put forward by non-Anglophone authors. Editing, thus conceptualised, is part mentoring and public service. Currently, there is little incentive or reward for academics to take on such an editorial role. Most academics are evaluated by their institutions on the basis of their published research, as opposed to their editing, mentoring or teaching duties. It will be hard for junior academics to take on such roles with the full support of their faculties, who will most likely advise them to focus on expanding their publication list.

\subsection{Facilitating the exchange of ideas and research collaborations}

While research access and capacity-building remove participation barriers and empower researchers, this part of the paper deals with collaboration for the mutual benefit of all involved. Using co-authorship as a 'rough' indicator, while recognising there are many other avenues for collaboration, legal research continues very much to be independently undertaken. A search from 2008 to 2013 of articles in the American Journal of International Law, the European Journal of International Law and the Chinese Journal of International Law, show that only 12 international law articles were co-authored. ${ }^{82}$ This paper however uses the term collaboration broadly, to refer to practices that facilitate the exchange of ideas, capture the 'joint effort' of the parties involved and bring their knowledge and expertise together in an equal manner. ${ }^{83}$ Thus defined, collaborative projects may include the publication of edited collections or anthologies, the design and deliver of co-taught courses or the organisation of co-hosted conferences.

There are many benefits to such collaboration: ideas can be sharpened and refined through discussion and more complicated research techniques can be used while preserving a subject's time-sensitive relevancy. Collaboration between scholars from developing and developed countries may facilitate not only the exchange of ideas but also the mutual transfer of skills and knowledge. Such collaborations broaden the perspectives and skill-sets of all those involved. Also, as academia becomes increasingly specialised, researchers with different specialisations can be brought together through collaboration to address complex

${ }^{82}$ Research data on file with authors.

83 'Opportunities, challenges and good practices in international research cooperation between developed and developing countries' (2011) OECD Global Science Forum [hereinafter 'OECD Good Practices'], 5. 
problems. ${ }^{84}$ Similarly, collaboration can also advance inter-disciplinary studies by bringing together researchers from different disciplines.

Collaboration is not always beneficial or positive. Sometimes, researchers enter into collaboration as this enables them to fulfil publication quotas set by their university. This focus on publication numbers may compromise on the quality of publications. ${ }^{85}$ In collaborations between scholars from developed and developing countries, the former may unconsciously impose his or her views or standards on the latter as a result of unexpressed power dynamics. Yet, collaboration, if planned and structured thoughtfully, can bring together researchers with different strengths and knowledge. It exposes and familiarises scholars from different legal traditions to the views of their peers and can be a way of making international legal research more diverse and inclusive.

\subsubsection{Enabling conference attendance}

Conferences provide researchers with networking opportunities that may lead to future collaboration. Despite developments in technology, such in-person meetings remain crucial to the formation of collaborative partnerships. However, many academics are simply not able to participate in global conferences due to the registration, travel and accommodation costs involved. This is particularly so for academics from developing countries. Academics from the developed world generally receive a comfortable salary and are able to fund their own costs. Some of these academics, though not all, may even be so fortunate as to obtain a conference budget from their institutions.

To ensure access to conference presentations and enable world-wide debate, conference organisers are increasingly making podcasts or videos of conference presentations available on websites. ${ }^{86}$ Still, attending conferences enables a researcher to learn about new developments in his or her field and connect with colleagues from other countries and institutions. Recognising this, quite a number of conference organisers are raising funds to pay for the travel and accommodation costs of speakers from developing countries. Such funding arrangements are, however, not common. Based on an internet search of international law conferences held from 2008 to 2013, 33 conferences offered

\footnotetext{
${ }^{84}$ Ibid.

${ }^{85} \mathrm{P}$ A Schrodt, 'If I ran the university', <http://eventdata.psu.edu/7DS/7DS.University.chpt.pdf>, 31 [accessed 15 October 2013].

${ }^{86}$ See for example the podcasts of conferences made available on the University of Oxford's website: <http://podcasts.ox.ac.uk> [accessed 22 September 2013].
} 
different levels of financial support to selected conference presenters. ${ }^{87}$ A number covered all conference-related costs; others offered reimbursement up to a certain amount; and others prioritised $\mathrm{PhD}$ students or participants from certain regions. ${ }^{88}$ Many of the conferences or workshops that provide such funding are recurring events and have long term goals, such as the development of young scholars. ${ }^{89}$ For some conferences, paper selection does not automatically entitle the presenter to funding or sponsorship. Selected presenters are required to make an additional application for a travel grant or a bursary. ${ }^{90}$

Promoting such funding practices is necessary to ensure better representation at conferences. A more 'no-frills' model of conferences may be necessary, with funds channelled instead to ensuring representative participation. Even so, conference organisers may find it difficult to secure the necessary funding and some have already experimented with creative solutions. For example, conference registration costs may be used to fund travel and accommodation bursaries for participants in need of these. Funders also need to be educated about the importance of inclusive conference participation and how travel and accommodation bursaries can further this.

Apart from ensuring representative conference attendance, organisers of global conferences should take steps to enable the effective participation of conference attendees who may not have English as a mother tongue or working language. Research shows that non-Anglophone academics are often worried about the negative impact of their English skills on their conference presentations. Concerns range from fearing that they will be unable to answer questions from the audience in a prompt yet clear manner, to dreading that they might fail to capture the attention of the audience through jokes and the 'smooth' use of the language. ${ }^{91}$ Conference organisers can address this by providing simultane-

\footnotetext{
${ }^{87}$ This 'snapshot' of conferences is based on information available on the internet as of July 2013. It should be noted that some conference organisers had removed details of funding once the conference had been concluded. For future research purposes, more detailed follow-up research beyond internet-based research is intended, in order to obtain a more comprehensive mapping of conference funding practices.

${ }^{88}$ Detailed research data on file with authors.

${ }^{89}$ Examples include the Biennial Conference of the European Society of International Law, the Biannual International Four Societies Conference, the Biannual Sean Maxwell \& Isle Cohen Seminar in International Law, the annual NUS-Asian SIL Young Scholars Workshop and the Annual Comparative Law Works in Progress Workshop.

${ }^{90}$ Examples include the Biennial Conference of the European Society of International Law or the IGLP Conference or Workshop series.

91 Pérez-Llantada, Plo \& Ferguson, above n 71, 28.
} 
ous translation services, particularly into the working or native language of the conference venue. Academic institutions could provide their non-Anglophone researchers with language support training. ${ }^{92}$ Such courses would be useful and, once developed, could be shared through the internet with other colleagues from developing countries. However, the most effective of such courses are those tailored to the native language of the target students. To illustrate, the difficulties encountered by Spanish-speakers in the study of English are very different from those experienced by Chinese-speakers. There is therefore less commercial incentive to develop such courses for researchers with a native language spoken by a relatively small number of people.

\subsubsection{Maximising collaborative opportunities}

Research collaboration may be implemented through various avenues, such as the publication of anthologies with contributions by researchers from different countries or continents. Such collaborative efforts could be further encouraged. For example, an observation made regarding a 2012 publication bringing together scholars from Europe and North America notes that it is a rarity to see a volume that includes scholars from both sides of the Atlantic. ${ }^{93}$ An objective standard which could serve as a measuring stick of diversity and representativeness in edited collections would be to aim for the inclusion of contributions of at least one-third women authors, one-third non-westerners and one-third authors under the age of $50.9^{94}$ Evidently, a researcher can belong to several categories. Research shows that to obtain a balanced outcome, a 'critical mass' of representative participants is required, as opposed to having a 'lone exception'. 95 Such a standard could also be applied when setting up conference panels. Ideally, the researchers involved in such collections would have had the chance to present

\footnotetext{
92 Being mentored by senior colleagues familiar with academic language discourse has also been suggested. Ibid, 27-28.

${ }^{93}$ K C Priemel \& A Stiller (eds), Reassessing the Nuremberg Military Tribunals: Transitional Justice, Trial Narratives, and Histiography (2012).

${ }^{94}$ An example of such a book is F Baetens (ed), Investment Law within International Law: Integrationist Perspectives (2013).

${ }^{95}$ Such research has been conducted with regard to the influence of historically excluded minorities in society more in general, see e.g. K S Thorburn, 'Comments on the Directive on improving the gender balance among non-executive directors of listed companies', Discussion at the ECGI-European Commission Workshop, Brussels, 23 January 2013; D A Patel, 'Once home to Kagan and Warren, HLS Faculty still only 20 percent female', The Harvard Crimson, 6 May 2013; D A Patel, 'Female HLS graduates enter a job market dominated by men', The Harvard Crimson, 9 May 2013.
} 
their contributions at a workshop or conference beforehand, where they would also have had the opportunity to ask each other follow-up questions. This would enable participants to discuss how their papers may be improved and how their ideas may be more clearly presented to audience from different legal traditions.

In addition to collaborative research, collaborative teaching has received substantial attention of late across all disciplines. It is believed that students benefit from being exposed to the different views and teaching approaches of various teachers. From a cross-cultural perspective, such exposure may raise the awareness and sensitivity of students to a panoply of legal cultures. In line with this, exchange programmes have become popular and some universities have embarked on collaborative teaching ventures that assemble lecturers from many countries. Academics also learn important skills in communication, understanding and empathy as they are required to design and deliver their lessons to non-native English speakers from different legal traditions.

Developments in communication have also enabled educators located in one continent to deliver lectures to students located in different continents. The widespread popularity of Massive Open Online Courses (MOOCs) show how online courses, if organised well, can be informative and engaging at the same time. ${ }^{96}$ Through video conferencing and other online platforms, lecturers from several institutions or countries could work together to co-teach a course in real time. Students from one class are able to pose questions to the lecturer and engage in discussions with students at another location. Further exchange between class participants and lecturers could be facilitated through a variety of online tools such as forums or blogs. However, to maximise the potential of these online tools, lecturers would need to be given sufficient training. The sheer variety of online platforms available to teachers and students may confuse and distract if they are not implemented well. Institutions would also need to provide their staff and students with facilities such as a good internet connection and functioning computers.

\subsubsection{Designing equal partnerships}

The design of collaborative projects is important. Collaboration aims to bring together individuals with different and complementary strengths. These individuals may also bring with them personal or cultural characteristics that undermine the collaborative project. ${ }^{97}$ Power imbalances between the parties may also

\footnotetext{
${ }^{96}$ See, for example, <https://www.coursera.org/> [accessed 8 May 2013].

${ }^{97}$ OECD Good Practices.
} 
undermine the spirit of collaboration, especially when one of them is a minority or from a developing country. Clear planning can address these potential setbacks. ${ }^{98}$ However, most funding opportunities and donors are located in developed countries. This means that the fund applicant will very often be an academic or researcher from an institution located in a developed country. The inclusion of other collaborative partners should be done at the planning or design stage and this is something that funders should require or strongly encourage. Funders, in other words, need to be educated on adopting an empowerment model when it comes to collaborative academic endeavours. Indeed, guidelines issued by the Organization for Economic Cooperation and Development (OECD) on collaborative research between researchers from developed and developing countries emphasise the need for careful planning right from the very beginning. ${ }^{99}$ These guidelines underscore the need to include researchers from developing countries in the project's planning process, rather than later. The objective is to avoid asymmetry and to reflect a 'true partnership' characterised by 'a balanced bi-directional flow of resources, efforts and benefits. ${ }^{100}$

To ensure this, collaborative projects need to outline, from their very inception, the expectations and goals of each party. The respective contributions of each party should also be identified. The OECD highlights the important contributions that researchers from developing countries can make, such as in-depth local or regional knowledge. ${ }^{101}$ It is for collaborating researchers to set the scope and boundaries of the project together at the very beginning. For example: who are the intended beneficiaries of the project and how will success be measured? There is also the question of accountability and auditing. It is also good practice to submit collaborative projects to independent third parties for their review and assessment. ${ }^{102}$

The final 'output' of the project should be determined early on, in a way that benefits both parties. This could be in a form of co-publication or co-presentation of the project's findings. It is important that credit and benefits from the project be shared equally among collaborators and in a way that is meaningful to each of them. For example, apart from publication in an international Anglophone journal, it may be useful for project results to be disseminated in a local journal or in a different language. Many international law academics conduct field research

\footnotetext{
${ }^{98}$ Ibid.

${ }^{99} \mathrm{Ibid}, 10$.

${ }^{100}$ Ibid, 5.

${ }^{101}$ Ibid.

${ }^{102} \mathrm{Ibid}, 14$.
} 
in foreign countries, including transitional societies. Such research does not by necessity require collaboration with local researchers. However, most need the help of local researchers to facilitate their access to certain actors or locations. Even at this level, the relationships formed between international researchers and their local contacts should ideally be well thought out and equitable. It should aim at benefiting both parties. A number of research-oriented organisations and fund providers have published ethical guidelines addressing the relationships formed by international researchers with local researchers and organisations. ${ }^{103}$

\section{Conclusion}

Implementing the suggestions put forward in this paper will not be easy as they challenge existing ways of thinking and doing in legal academia. Institutional resistance or inertia is to be expected. Most academic institutions and, specifically, law faculties do not embrace change easily. The internationalisation of practices and standards might discourage some institutions or individuals from adopting changes as these may undermine their global standing among their peers. Many individuals and institutions have invested significant time and resources into crafting career and development plans based on existing practices and norms. What then can we do as individual academics? What is the balance to be struck between acting boldly and yet wisely? How can institutions support individual academic decisions or pave the way for bold action?

With respect to the teaching of international law, clear commonalities exist in the choice of international law topics in the examined course curricula, although the precise content and approach may differ. Broadly speaking, two trends can be discerned in the use of teaching and reading materials which roughly seem to be based on the common versus civil law divide: a heavy focus on the development of international rules through case law versus an emphasis on the theoretical structure of the system, as analysed in scholarly writings. The present paper urgently calls for a re-evaluation of the teaching part of international law lectureships whereby junior and senior lecturers share the course convening and teaching load. Teaching too much of a variety of courses makes it impossible for lecturers to remain up-to-date with developments in each of these fields-to the detriment of the academic quality of their lectures and, ultimately, the education

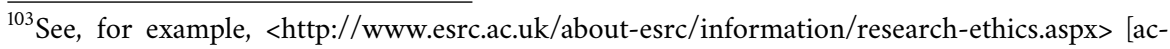
cessed 8 May 2013]. 
of their students. This paper advocates the adoption of a system whereby all members of staff annually have to earn a number of 'skills credits'.

The 'academisation' of the international law lectureship has seriously impoverished the capabilities of lecturers to link international law and practice in a meaningful manner, so lecturers should be allowed and encouraged to obtain practical experience, be it through litigation, NGO or in-house counsel work. Moot courts form excellent preparation for legal practice-a finding which is increasingly recognised by law schools, funding agencies and academic and professional societies. In addition to supporting the travel and accommodation costs of teams, students can be rewarded for the time invested, by incorporating moot courts in the curriculum and offering course credit for participation. Efforts should be made in terms of offering internship and clerkship opportunities more widely as well as procuring funding for students to take up such positions. This analysis of teaching practices served as a basis for the subsequent section, in which a number of best practices in relation to the research of international law are set out-as the essential foundation upon which university-level teaching is based.

In terms of international law research, it would not be wise for early career academics to solely publish in open access journals without considering the journal ranking system used by his or her institution. Rather, one could balance one's commitment to open access and the demands of one's institution by choosing an open access journal that is respectably ranked. Or one could choose to spread out one's publications by publishing in open access journals as well as 'ranked' journals that do not practise open access. As for academic institutions, they may be hard pressed to ignore the global practice of ranking journals, but more attention could be paid to the content of publications when assessing staff performance instead of using journal rankings as primary or sole measures of research quality. Individual academics and institutions can explain their decisions to depart from existing practices, with the objective of further spreading their message. In other words, there are indeed steps that individual academics and institutions can take, small incremental ones that may contribute to wider cultural change.

We do not call for the immediate and indiscriminate extinction of all current practices. For example, it continues to make sense to organise the occasional high-cost conference aimed at bringing together high-ranking diplomats, donors and academics for fund-raising purposes. However, a commitment to inclusion and diversity would require more academic conferences to provide travel and accommodation bursaries. Also, while change does not happen overnight, this paper intends to start a critical discussion on how international law is 
being taught and researched around the world. Based on the teaching trends ascertained in this paper, is there a detrimental regional 'fragmentation' of international law teaching? Are the voices of junior scholars and scholars from developing countries being sufficiently nurtured and included? Will the teaching and researching of international law become disconnected from practice or fail to be truly representative of diverse viewpoints? These are questions that need to be debated in an open-minded and transparent manner. The authors hope that the list of best practices outlined in this paper will form the foundation upon which more innovative practices from within the field of international law can be implemented and shared. If we subscribe to a vision of international law that is inclusive and diverse, we cannot but bring our teaching and research practices into alignment with our beliefs. 